\title{
TO THE QUESTION OF THE AXIOLOGICAL MODEL OF LEARNING LITERARY EDUCATION IN THE MODERN SCHOOL: FROM TRADITIONS TO INNOVATIONS
}

\author{
Golikova Guzel AZGAROVNA \\ Kazan Federal University \\ guzel-golikova@yandex.ru \\ Motigullina Alfia RUHULLOVNA \\ Kazan Federal University \\ alfiya311065@mail.ru \\ Zamalieva Luiza FIRDUSOVNA \\ Kazan Federal University \\ zamalluiza@mail.ru
}

\begin{abstract}
This paper touches upon the relevant aspect of modern education, that is the theoretical justification and designing of the axiological model for studying liberal arts. The historical review presents the issues of establishment of axiology, defines the conceptual axiological ideas in education and unravels the concept of "value". An important question here is the development of a psychological mechanism for formation of values within a student's personality during the studying process. As follows from the ideas of Nikolay Lossky, one of the main aspects of establishment of the value formation mechanism is the emotional component. The deciding role here belongs to the student's subjective experience, which contributes to realization of the axiological approach. Having analyzed the theoretical works on this issue, we can determine a productive value formation mechanism in the literature and culture classes, which we believe to be the mechanism of text interpretation based on the reader's valueconscious and emotional interaction with a literary piece. Basing on the M.Baktin's ideas of dialogicality, it is important to observe an equally rightful value-conscious dialog between the author, his writing and the young reader in the process of artistic-aesthetic dialog, which is supported by the development of various types of literary text interpretation. Thus, the interpretation, as a mechanism of understanding a literary text in aspects of poetics and aesthetics, becomes a mechanism of adopting eternal values of humanity by an individual through education.
\end{abstract}

Keywords: axiology, values, eternal values, subject, subjective experience, internalization, interpretation

\section{GÜNÜMÜZ OKULLARINDA AKSIYYOLOJIKK MODELİ KULLANARAK EDEBIYYAT DERSLERININ KURULUŞU MESELESİ: GENELEKSELDEN YENILIKLERE}

\section{ÖZ}

$\mathrm{Bu}$ makalede günümüz pedogojisinin önemli olan bir yönü - beşeri alanda aksiolojik modelin, eğitimde teorik gerekçesi gözden geçirilyor. Tarihi alanda aksiyoloji feninin gelişimi öğrenildi, pedogojide konseptual aksiyoloji kavramı ayarlandı, 'değer' kelimesinin anlamı açıklandı. Önemli mesele olarak öğrencilerde insani değerleri oluşturan psikolojik mekanizmaların eğitim sisteminde gelişmesi belirlendi. N.O. Losskiyın fikirlerini takip ederek, insanın değerleri kabul edip etmemesinde önemli olan 'duygu' bileşkesi bulundu. Bunda çözümleyici rol, öğrencinin subjektif tecrübesine ait ve aktüalitesi, öğrenme sürecinde aksioloji yaklaşımı kullanarak gerçekleşmesinden ibaret. Bu mesele ile ilgili kuramsal eserleri analize edip, edebiyat ve ahlak derslerinde değerleri etkili bir şekilde kabul etme mekanızmasını kurup, biz, eseri yorumlama mekanizmasının temelinde okur ile yazarın değeriduygusal iletişimini gördük. M. Bahtinın diyalogizm fikirine göre, edebi-estetik diyalog sürecinde, 
yazar ile genç okur arasında eşit haklı iletişim kurulması lazım. Buna ise edebi eserlerde degişik janr kurulmaların yorumlaması yardım ediyor. Yorumlama, edebi eseri şiirsel ve estetik yönde anlama mekaniznizması olarak, ebedi değerleri öğrenme sürecinde özümleme mekanizmasını yetiştiriyor.

Anahtar kelimeler: aksiyoloji, değerler, ebedi değerler, özne, öznel deneyim, içselleştirme, yorumlama

\section{INTRODUCTION}

Axiology (from Greek axia "worthy" and logos "science") is a philosophical study of value and the structure of the value world. It is a science "of values of the world and human, contents of an individual's inner world and its system of values" (Ananiev, 1980). “...the world we live in is driven not only by the unconscious forces, but also, more importantly, by human values... and that the fight for saving the planet ultimately becomes a fight for values of a higher rank" (Sperry). Sperry justified the necessity of creating an axiological science, studying the universal values, providing unified favorable existence of human and the world. The main provisions of axiology, as a study of the nature of values of the society's spiritual life and culture, were developed by Russian scholars, such as S. Anisimov, L. Arkhangelsky, L. Bueva, O. Drobnitsky, A. Zdravomyslov, V. Tugarinov etc. Technically, the axiological stage in international philosophy is believed to start with the launch of three volumes of "Microcosmus", a book by Rudolf Hermann Lotze (1856-1864). The term "axiology" was first used by Paul Lapie and E. von Hartmann in the early $20^{\text {th }}$ century. They outlined a new and eventually separate branch of philosophy, dealing with problematics of values, introduced an independent concept of "validity" (Geltung) as opposed to existence, that does not depend on experience and performs as a standard of truth in cognition, and, as a result, have started the development of value problems. While developing this trend, the philosophers of Baden (Wilhelm Windelband, Heinrich Rickert etc.) and Marburg (Hermann Cohen etc.) Schools of Neo-Kantianism, other than the concept of "validity", used the concepts "ought to be" (sollen) and "value" (wert, value, valeur- from Latin Valere "to be worthy"). They divided the entire real world into reality (existence) and values, which do not exist, stand outside and above the reality, on the other side of an object and subject, being for the latter only an objective obligatory validity and "oughtness". Heinrich Rickert wrote that the essence of values "lies within their validity rather than their facticity" (Rickert, 1911, p.128). The Neo-Kantians of the Baden School were the first philosophers to create a systematic theoretical study of value, where the concept of value have become the most important philosophical category.

By the beginning of the $20^{\text {th }}$ century, philosophy had outlined its attitude towards values, their specifics, their part in the life of human and society. The problems of values were also developed by philosophers-positivists. It refers to the representatives of new realism (Ralph Perry), naturalism (T. Manro), pragmatism (John Dewey), contextualism (St. Peper) and emotivism (Charles Ogden, Ivor Richards). Neopositivism (from Bertrand Russell to Ludwig Wittgenstein) defined the axiological judgements unverifiable and, thus, irrelevant to truth and science.

The axiological vision had discovered the philosophy of Religious Renaissance. It unravels the spiritual content of universal human values as an internal basis of human unitotality. The Russian philosophers (from V. Solovyev to Nikolay Lossky) showcased the deep interrelation and organic unity of triad of the $20^{\text {th }}$ century: Spirit-Freedom-Personality. They saw the axiological origins of human existence within the divine spirituality rather than in cognizing mind. Nikolai Berdyaev wrote that "spirituality brings liberation; it brings humanity. Spirit, freedom, personality have a nominal meaning... There is a way for spirituality to break through into the social life, as all the best of the social life comes from this source. We have to leave this completely false idea of the second half of the $19^{\text {th }}$ century, that human is a creation of social medium, behind. On the contrary, the social medium is a creation of human being" (Berdyaev, 1993: 324). According to Nikolay Lossky, "life as a whole is driven by the love for values (Lossky, 1991: 182). Berdyaev is an advocate of values of individualism. His philosophy is of personalistic nature. He defends the value of personal freedom. He believes that "the actual solution of the problem of reality, problem of freedom, problem of personality is a true test for any kind of philosophy". Nikolay Lossky wrote about Nikolai Berdyaev the following: "Berdyaev is particularly interested in problems of personality... it is not a part of society, but on the contrary, 
society is just a part or aspect of a personality. Personality is not a part of cosmos, on the contrary, the cosmos is a part of human personality" (Lossky, 1991).

In the first third of the $20^{\text {th }}$ century axiology was actively developed. The true and effective study of society based on the method of "referring to values" by H. Rickert, that was further developed by Max Weber and others, was sociology. One of the most prominent sociologists of the $20^{\text {th }}$ century P. Sorokin "revolutionized the theory of sociology by subjecting the latter to the values as a main motivational driving force in society". He proved that "sociology is predominantly a theory of value" (Covel, 1979: 49). By the second half of the $20^{\text {th }}$ century axiology had secured its position in the human science. Before the early 60s axiology was officially banned in Russia as a bourgeois "pseudoscience". And only in 1960 the monograph "On values of life and culture" by V. Tugarinov was published, which initiated the development of the main axiological concepts from the position of Marxism (Tugarinov, 1960). In 1964, V. Vasilenko released a book called "Value and evaluation". The philosophical discussion of the problem of values was held in the Soviet Union for the first time in 1965 (Tbilisi). Thus, it was a start for the development of value problems in philosophy, sociology, pedagogy and psychology.

\section{RESEARCH QUESTION}

The axiological approach has become one of the most crucial in pedagogy. It is one of the most meaningful from the point of humanization of cultural-educational sphere, as well as the social sphere in its broader meaning. The aspect of axiological justification of culture and education acts as a base for conceptual foundation of axiological approach to culture and education of M. Duranov, O. Lesher, A. Saranov, V. Slastenin, L. Ustinova-Baranova and other researchers. The works by A. Asmolov, V. Kan-Kalik, A. Petrovsky, K. Platonov and others allow us to consider the axiological approach to studying within the framework of the theory of communication as a type of human activity.

The axiological approach is peculiar to the humanistic education, as here person is considered as the highest value of the society and a goal of the social development in itself. As a result of its application in education, the axiological approach has led to the idea of humanization of education, which has a wide philosophical-anthropological and sociopolitical meaning, as the strategy of social movement depends on its solution, which might either slow the human development down, or encourage it. The problems of moral education are traditional for the Russian school, however, nowadays it concerns not as much the digestion of the system of values, acknowledged by all the members of "adult" society, by students, but rather the organization of the axiological choice in the broad spectrum of values of the modern civilization (confessional, ethno-cultural, regional, national (state) and others).

Today, the essence of the axiological approach in education is first of all defined by the situation of evaluation (worldview (political, moral, aesthetic etc., evaluation of occurring events, problem statement, search for solutions and making decisions and their implementation), which human is constantly exposed to, defining his attitude to the world and himself. Nowadays, there are several axiological principles in humanistic education that claim to become principles of other related sciences, aiming at integration with the humanistic education.

\section{The axiological principles may include the following:}

- $\quad$ equality of all philosophical views within the unified humanistic system of values (while keeping the diversity of their cultural and ethnic peculiarities); - equivalence of traditions and creativity, acknowledgement of necessity of learning and use of studies of the past and the possibility of discoveries in the present and future; - equality of people, pragmatism instead of disputes about the justification of values; dialog instead of ignorance to or negation of each other.

The humanistic education builds its conceptual foundation on the basis of principles and categories of axiology, justified by the Russian and foreign philosophers. The crucial axiological category is a category of value. The first and most popular understanding of value is as significance of objects and phenomena of reality to human, their capability to satisfy his material and spiritual needs. The concept is most subsequently presented in the works of V. Vasilenko and his supporters (Vasilenko, 
1964). Here, value comes down to a means of satisfying one's needs, that is to usefulness as positive significance. The representatives of the second version, most subsequently summarized by I. Narsky, refer to values only as the highest godly ideals (Narsky, 1976). From this point of view, values are a goal rather than means, something that is ought to be rather than exists. This concept became most popular in ethics. Nikolay Lossky defines God as the main and absolute value. "The difficulty lays in definition of the one absolute positive value, which is God as the Good itself, absolute completeness of existence, meaningful in itself, justifying it, making it the subject of approval, giving it unconditional right to be implemented and preference over anything else" (Lossky, 2000). All the values are defined by the philosopher with categories of "good" and "evil". Hence, the positive and negative values. Lossky separates absolute values from relative ones, objective from subjective. The absolute value is God and the Kingdom of God, which in the psychomaterial world are also expressed through the categories of "love" and "beauty".

The third approach unites the initial foundations of the first two. The conceptual foundation is developed in the works by V. Tugarinov and O. Drobnitsky (Tugarinov, 1960; Drobnitsky, 2002). The problem of values from the perspective of the theory of social essence of an individual is presented in the writings of B. Ananiev, A. Bodalev, B. Kruglov, A. Leontyev, R. Rogova and others. The problem of values is also in the picture of psychological and psychological-educational researches of $\mathrm{F}$. Apish, G. Borlikov, T. Yevmenova, A. Kiryakova, L. Pokhilko, N. Chuvatova and other authors, who paid particular attention to the formation and development of needs, motives, aspirations, value system and personality orientation.

Summarizing the definitions of values, suggested by various scholars, we can say that values are material or ideal objects, holding significance to the given social subject from the perspective of satisfying his needs and interests. This generalized formulation may serve as a summary of all these numerous definitions of values existing in the Russian and western scientific spheres. According to the philosopher I. Frolov, "value is a real marker of human behavior, forming people's living and practical attitudes". In turn, derivative from them value orientations are attitudes of an individual towards the values of material and spiritual culture (Zdravomyslov, 1986, p.197). Overall, value is an interpretation, interpretative construct, in which the subject expresses his preferences. The nature of the very interpretation is defined by the philosophy used by the subject. Values are formative units of an individual's consciousness that define the relative constant attitudes of a person to the spheres of life: world, other people, himself. This assembly of attitudes essentially forms the moral position of an individual, which becomes particularly strong with its acknowledgement, with the occurrence of personal values, considered as conscious general semantic formations (Bozhovich, 1961).

\section{METHODS}

\section{MODELING OF THE VALUE FORMATION MECHANISM OF AN INDIVIDUAL IN THE COURSE OF EDUCATIONAL ACTIVITIES}

A relevant problem in pedagogy and education for today is a question of value formation mechanism of an individual, a mechanism of adopting values by a concrete individual. The formation of value orientation is a quite complex process that has an essentially nonlinear time span. The process of value formation does not manifest itself in human behavior at all stages. It is an internal, intimate personal process of value formation within a human being, a path of his personal self-identification.

While determining the psychic mechanism of value formation within a human consciousness, Nikolay Lossky writes that "values enter the subject's consciousness through none other than feelings of the subject, intentionally directed at them. In connection with the subject's feelings, they become values experienced by him" (Lossky, 2000). "They are already connected with the positive and negative forefeeling even in the preconsciousness". Lossky predetermined the provision on the important influence of values on the individual's concept of "self". The values themselves are not connected to the person's activity, as they only predetermine it and form a life "route". "The values themselves do not hold any power that could create aspirations of the subject and his activity; the dynamic moment of aspiration and activity belongs to the subject himself, the substantial agent himself and no one other (or rather "nothing", as the words "one" and "no one" can refer only to substantial agents). 
The formation of value "routes" of a student individual in the process of studying culture and literature is closely connected to the peculiarities of the student's personality structure. A great part in the development of conceptual foundation of axiological training goes to the concept of "subjective experience" of a student. Subjective experience is an individual experience of life activity based on the functional capabilities of the organism, conditions of the educational system and the subject's own psychic activity (the complex of individual cognitive, communicative and creative experiences of capturing the reality) (Yakimanskaya, 1996). It is a life experience saved in the reserves of long-term memory and capable of updating in suitable conditions (Svinina, 2001).

A. Osnitsky uncovers five interconnected and interactive components of this experience:

1. Value experience (related to formation of interests, moral norms and preferences, ideals, beliefs). It orients the person's efforts.

2. Reflection experience (gathered by a person by placing his knowledge about his abilities and possible transformations in the objective world and within himself against the requirements of activity and the addressed problems). It helps to bind the orientation with other components of the subjective experience.

3. First activation experience (referring to preliminary preparedness, immediate adaptation to changing working conditions, calculation for specific efforts and specific level of success). It orients in one's own abilities and helps to adapt the efforts towards the solution of important problems.

4. Operational experience (including general working, professional knowledge and skills, as well as the skills of self-regulation) combines the concrete means of transforming the situation and one's own abilities.

5. Cooperation experience (forming through interaction with other participants of the joint activity) contributes to joining of the efforts, joint problem solution, presupposes preliminary calculation for cooperation (Osnitsky, 1996:14-15).

Based on this structure, we can see that such formations in an individual, as values, in psychology often referred to as personal meanings, play an important part in subjective experience. The nature of personal meanings changes with the human's age periods, the individual makes choices in his value system more assuredly. While developing throughout the human's entire life, the subjectness has its objectives in every age stage, its phenomenology and forms of development. The basis of formation of the value adoption mechanism in education, where the student's emotions stand as a by no means unimportant factor, relies on the subjective experience of the student, his development, in terms of values as well, and "cultivation" of this experience (the term by I. Yakimanskaya).

The individual system of values forms through inclusion of the individual in culture. From this perspective, the liberal arts education has a special pedagogic orientation, as well as a special mission and objectives of axiological nature. The individual becomes a personality during the very process of cultural education (material and spiritual), as a person is a human, whose combination of properties allows him to live in society as its rightful and full-fledged member, interact with other people and perform activities to produce cultural objects. Culture is "a directional human effort which changes not only the natural environment, the initial object of this effort, but also the human himself" (Artanovsky, 1988: 25). It is "the highest level of improvement, spirituality and humanity of the natural and social conditions of life and human relationships, assimilated by the living and passed on to the next generations" (Vyzhletsov, 1996: 25). It is also a phenomenon of human spirit, as an internal essence of human ideas, symbolically fixed activity of people, illuminated with humane and moral goals (Kagan 1996: 70). According to Semyon Frank, culture is "a combination of ideal values" (Frank, 2000). Literature is a part of spiritual culture, so the familiarization with the art of words becomes an important stage in the formation of the system of values within the personality of a human being. Hence, the importance of developing a special mechanism for adoption of values during the lessons of literature.

\section{RESULTS}

The theoretical data and many years' experience of Tatarstan's literature teachers in observation and analysis of educational work lead us to the following conclusions concerning the implementation of 
axiological approach in education. The main professional objective of a teacher, who follows the humanistic ideas in pedagogy, is to create an axiological interaction between the two subjects of education, that are the literary text and the student reader during the lesson using different devices and working forms. "The literature teacher faces a complex and at least two-sided challenge: firstly, to make sense of the literary read as an axiological literary formation, carrier of the "emotional value orientation" (the term by A. Yesin), secondly, make sense of the process of dialog between the student reader and the literary piece itself as an axiological structure (according to M. Bakhtin). In the structure of this dialog the subjects of reading dialog (here, the Book and the Reader) are equally rightful axiological elements. The Reader opens not only the meaning of the literary piece, but of himself as well; he digests not only the fictional reality of the literary piece, its values and ideas, but also "digests" the values of his own personality (the process of development and self-development, self-actualization)" (Golikova, 2014).

Being versatile, the artistic-aesthetic dialog, created during the lessons of literature, must be built on the basis of value interaction between the "self" and the "other", crossing distances in aesthetic and value positions of the two subjects: the Author and the Reader. Thus, it is necessary to skillfully match the self and the other as natural oppositions in understanding of the writing (Wilhelm Dilthey, Mikhail Bakhtin, Hans-Georg Gadamer, Paul Ricœur) in the process of analysis and interpretation of the literary text, comprehension of it during class and outside of it, to create the dialog based on the transformation of the position I-I into the position I-Thou (M. Buber), which is logically determined by addressing the subjective life experience of the readers (Buber, 1999).

The phenomenon of value dialog during the comprehension of a literary piece is objectively implemented through the reader's interpretation. It is precisely the reader's interpretation that makes the dialog between the reader and the literary piece and its author effective and productive and, as we believe, becomes the main value adoption mechanism during the lessons of literature and culture. The foundation of this value dialog-interpretation is "the give-and-take of question and answer" (according to M.Bakhtin and H.-G. Gadamer), where the categories of question and answer are imbued with individuality of both the author and the reader. Here we rely on the provisions of the theory of interpretation, developed in the classical and newest researches of this problem (foreign and Russian): Friedrich Schleiermacher, Wilhelm Dilthey, Hans-Georg Gadamer, Paul Ricœur, Roland Barthes, Julia Kristeva, Jacques Derrida, Alexander Potebnja, Arkady Gornfeld, Yuri Lotman, L. Chernets, B. Yesin, E. Tsurganova etc. Interpretation is seen as explanation of a text, "understanding of the entire meaning of the literary piece, its ideas and concepts" (Yesin, 1998: 164). As opposed to the scientific analysis of text, interpretation is emotionally colored, which allows the teacher to implement the value "acquisition" mechanism. Interpretation essentially combines the scientific understanding of the text, the reader's emotions and his subjective experience. This psychological complex leads the reader to the "axiological" understanding of the literary piece, to the value "acquisition" site. The Literary text interpretation work in each class must conform to the developmental age of the students. At the same time, it is important to pay attention to the genre of interpretation. For instance, students' creative work can be in a form of pastiche inspired by the already studied literature genres (folk song, ode, epistle, epigram, elegy, letter of a fictional character, character's diary, prose poem, travel memoirs, monument for a fictional character). For high school classes it is suggested to compare the literary styles, genres of different periods (Marantsman, 1998: 24). For lessons of modern literature, it might be quite effective to use the following types (genres) of interpretation: - scientific (expressed in the works of prominent literary critics), - critical (represented by literary criticism, both classical and modern), - artistic (comprehension of literature through other forms of art: painting, music, cinematography etc.), - readers' (personal outlook on the text, in this case, of the student reader) (Marantsman, 2003: 22).

\section{DISCUSSION AND CONCLUSION}

Thus, the axiological approach in liberal arts education is one of the components of the systemic activity approach. In order to develop a model of axiological "routes" in studying a specific subject it is important to understand what a value is. Values are a moving force of personality, a governor of its behavior. It is necessary to solve the problem of implementation of the value adoption mechanism in 
liberal arts education. The key to design such mechanism is a notion of "subjective experience". By virtue of their specific subject matter, the school subjects "Literature" and "World artistic culture" contribute to the formation of value constructs in the personality structure of a student and the familiarization of students with the global values of humanity to the biggest extent. The productive axiological communication with a literary writing in its entirety is supported by the process of interpretation based on: 1) the emotional activity approach (Paul Ricœur), which we define as cocreation, 2) the process of self-understanding (Gadamer, 1988).

It is crucial to use various genres (types) of interpretation, as well as consider the hermeneutic methods, which can be implemented in class through nontraditional devices, such as "Write a letter to the character", "Create a picture", "Describe the color scheme of the text and paint it" etc. We suggest using these devices at different stages of the lesson: 1) at the stage of setting a directive towards the perception, "entrance" to the text, 2) at the stage of studying the specific structure of the writing (the system of images and the image of a specific character, image of the author, composition, style, plot, the elements outside the plot, poetics of the title) and its non-structural elements (subject, problems, message), 3) at the stage of final comprehension of the text, summarizing in the process of understanding (interpretation) of the writing. This approach allows to study literary pieces in school more effectively with consideration to not only their aesthetic diversity in the unity of form and content, in the interaction of a part and the whole, but also in the implementation of the axiological dialogical unity "reader-writing".

\section{REFERENCES}

Ananiev, B.G. (1980). Selected Psychological Works: in 2 vol. Vol.1. Moscow. Artanovsky, S.N. (1988). The Absolute Value of Personality. Vestnik LGU. 20. 23-31.

Bakhtin, M.M. (1986). [The] Aesthetics of Verbal Art. Moscow.

Berdyaev,A. (1993). The Destiny of Man. Moscow

Bozhovich, L.I. (1961). Personality and Its Formation in Childhood. Moscow.

Buber, M. (1999). Zwei Glaubensweisen. Moscow.

Covel, F. R. (1970). Values in human society. The contributions of Pitirim A. Sorokin to sociology. Boston.

Drobnitsky, O.G. (2002). Moral philosophy: Selected works. Moscow.

Frank, S.L. (2000). Sochineniya [Essays]. Moscow.

Frolov, I.T. (1983). The Prospects of Man. Moscow.

Frolov, I.T. (1985). On Life, Death and Immortality of Man. Moscow.

Fromm, E. (1993). Psychoanalyse. Ethik. Moscow.

Gadamer, H.-G. (1988). Truth and Method. Basics of philosophical hermeneutics. Moscow.

Golikova, G.A. \& Vafina, A.Kh. (2014). Axiological approach in education (Human-CultureLiterature). Pedagogika I prosveshchenie, 1, 22-29. DOI: 10.7256/2306-434X.2014.1.12098

Kagan, M.S. (1996). The Philosophy of Culture. Saint-Petersburg.

Kogan, L.N. (1984). The Purpose and Meaning of Human Life. Moscow.

Lossky, N.O. (1991). History of Russian Philosophy. Moscow.

Lossky, N.O. (1991). Terms of Absolute Good. Moscow.

Lossky, N.O. (2000). Value and Existence. Kharkov-Moscow.

Marantsman ,V.G. (2003). Objectives and structure of the literature course in school. Literatura v shkole. 4. 21-24.

Marantsman, V.G. (1998). The Interpretation of Art Work as a Communication Technology. Literatura v shkole. 8. 91-98.

Narsky, I.S. (1976). Western-European Philosophy of the $19^{\text {th }}$ century. Moscow.

Osnitsky, A.K. (1996). Problems of Subjective Activity Research. Voprosy psikhologii. 1. 5-18

Rickert, H. (1911). Sciences of Nature and Sciences of Culture. Saint-Petersburg.

Svinina, N.G. (2001). Students' Life Experience in the context of Personality-oriented Education.

Pedagogika. 7. 27

Tugarinov, V.P. (1960). On the Values of Life and Culture. Leningrad.

Vasilenko, V.A. (1964). Value and Evaluation Kiev.

Vyzhletsov, G.P. (1996). Axiology of Culture. Saint-Petersburg. 
The Turkish Online Journal of Design, Art and Communication - TOJDAC July 2017 Volume 7 Issue 3

Yakimanskaya, I.S. (1996). Personality-oriented Education in Modern School. Moscow

Yengin, D. (2017). İletişim Çalışmalarında Araştırma Yöntemleri ve Uygulamaları, Der Yayınları, İstanbul.

Yesin, A.B. (1998). Principles and Devices of Literary Analysis. Moscow.

Zdravomyslov, A.G. (1986). Needs. Interests. Values. Moscow.

Zdravomyslov, A.G. \& Yadov, V.A. (1966). Attitude towards Labour and Value Orientations of the Personality. Sotsiologia v SSSR. 2. 187-207. 